\title{
THE IMPACT OF CORONAVIRUS (COVID19) PANDEMIC ON HIGHER EDUCATION INSTITUTIONS (HEIs) IN YEMEN: CHALLENGES AND RECOMMENDATIONS FOR THE FUTURE
}

\author{
Ahmed Abdulkarem Al-Baadani ${ }^{1}$, \\ Mohammed Abbas ${ }^{2 \mathrm{i}}$ \\ 'Secretary-General of the \\ Emirates International University, \\ Yemen \\ ${ }_{2}^{2} \mathrm{PhD}$ Scholar, \\ Anadolu University, \\ Turkey
}

\begin{abstract}
:
Since the beginning of this year, the world has lived in one of the most difficult stages since the Great Depression during the 1930s. All sectors have been affected significantly because of the suspension and other actions that have been taken, such as social distancing and self-isolation that has occurred because of Coronavirus (COVID-19) Pandemic. This has affected the education sector, particularly Higher Education Institutions (HEIs) in the world in general and Yemen in particular. Universities in Yemen as a result, stopped their activities preventively to contain the spread of the novel corona virus among students. Each country reacted in a different way based on their capabilities. Some countries immediately shifted to online education and others faced obstacles however, country like Yemen is under great pressure from different aspects. As a result, this procedure caused many challenges for higher education institutions in Yemen which prevent an easy adaptation to the new situation such as: internet and infrastructure weaknesses, cope with change difficulties, academics career stability, university's financial stability, the complexity of some applied disciplines, student's mental health, and costs of fast transformation. As a result of the mentioned challenges, this study suggested some recommendations to overcome from this situation or any other urgent situations in the future that may shutdown the educational system. Finally, because of the complex and interrelated difficulties in Yemen, the authors suggested an implementation through a 5-year plan under the direct supervision of the Ministry of Higher Education in Yemen.
\end{abstract}

Keywords: Coronavirus, higher education, universities, challenges, Yemen

i Correspondence: email ahmed.badany@eiu-edu.net, mah abbas@anadolu.edu.tr 


\section{Introduction}

The capital of Hebei Province in China, the city of Wuhan, saw a new lower respiratory tract illness starting on December 31, 2019. The pandemic of Severe Acute Respiratory Syndrome Coronavirus (SARS-CoV-2) positively named as COVID19 was discovered by Chinese researchers (Chahrour et al., 2020). Several nations around the world have already placed transport limits in order to avoid the spread of the epidemic in order to tackle COVID19. Public health authorities or government officials undertake a range of methods, including social separation, self-isolation or containment; improve prevention and treatment healthcare facilities; and requesting people to work from home (Bedford et al., 2020; Chahrour et al., 2020).

From an economic point of view, no precise indication is given of the economic harm sustained by a worldwide COVID 19 coronavirus pandemic and economic experts concur that it will have severely negative effects on the world economy. As per initial statistical projections, most advanced countries will end up losing at least 2.4 percent of gross domestic product (GDP) and decrease their productivity growth predictions from around 3.0 to 2.4 percent in 2020. On other hands, in 2019, global GDP was expected to be about US\$ 86.6 trillion - which indicates that a decline of almost US\$ 3.5 trillion in economic growth corresponds to a mere 0.4 percent (Duffin, 2020). But these predictions were made before COVID19 became a global epidemic and human interaction constraints were imposed in order to prevent the propagation of the viral infection.

After the pandemic was announced officially by the World Health Organization (WHO) on 11 March 2020, Ma et al. (2020) emphasized that GDP growth decreases in low-income countries experiencing a medical crisis are on aggregate less extreme than in developed economies experiencing a health problem. For 2020, forecasts vary from $8.8 \%$ (WTO) to $1 \%$ (UNDESA, optimistic scenario). The IMF is the primary benchmark to evaluate the financial consequences of COVID19 among these estimates. Global economic growth will therefore decline by $-4,2$ percent, 7 points difference compared with the precrisis estimates (UNIDO, 2020).

Higher Education Institutions (HEIs) are usually struck hard in periods of economic instability because of absence of strategic planning. The epidemic of the COVID19 is anticipated to have a significant effect on the world economy, and universities are more susceptible to catastrophes than any other institutions (Alharbi, 2020). The economic harm anticipated in the education industry is -90 percent in countries such as UK (Partington, 2020).

According to (Zhaohui, 2020), the organizational culture and agility of universities was another hurdle, with a large number originally aimed at transferring content to online learning. However, it was also an illustration of the impact on organizational responses or student capacity to interact with the online environment of inadequately resourced institutions and socially deprived learners, with restricted availability to information technologies and the Internet (Zhong, 2020). Many intellectuals doubted 
whether higher education was prepared for the digital era of learning (Joseph Crawford et al., 2020).

Accordingly, the aim of the article is to shed light on the difficulties and challenges facing higher education institutions in Yemen, with a set of recommendations that might help the educational sector to overcome the impact caused by (COVID19) Pandemic.

\section{Impact of Covid19 in Higher Educational Institutions (HEIs)}

Education is one of the determinants of economic development and play a crucial role to shape human capital in the world. Nevertheless, Covid19 inevitably impacts all sectors in the whole world. The whole education sector has also been seriously impacted by the corona virus, a major portion for the future as well as for the present duration of development. China and South Korea were first to be impacted by the virus (Bassett \& Arnhold, 2020). However, within weeks the epidemic was worldwide, all continents and nearly all countries had to respond.

Public health issues frequently trigger confusion and anxiety, and Higher Education Institutions (HEIs) seldom take time to recognize and create possible approaches that may arise and impact them. As a result of Covid19, most nations are totally shut down to safeguard humans from the propagation of corona virus by the communities of all socio-economic activities and human movements. Likewise, after an epidemic of Severe Acute Respiratory Syndrome (SARS) in China several schools and universities suspension occurred in 2003 (Toquero, 2020). The influence of the SARS Epidemic took HIEs two years for recovery (Dennis, 2020).

On the same direction, the epidemic COVID19 has a huge implication on higher educational institutions. The time of the recession of corona virus is unclear for universities around the globe. As a result, there is uncertainty about how long the coronavirus crisis will last and how. Universities are expected to skip a whole semester or much longer in the impacted regions (Ross \& Lau, 2020). Projections expect a $15 \%$ to $25 \%$ reduction in enrollment, based on which region of the planet is measured (Dennis, 2020). Throughout COVID19 Crawford et al. (2020) outlined the reaction of several universities through 20 countries and demonstrated diverse responses to the complex challenge. The reaction to the current challenge was to promote or authorize online learning through live streaming on Facebook, YouTube, Zoom and home e-learning portals by the majority of Malaysia's twenty government universities starting from 16 March 2020 (Lim, 2020). On other hand, The students in India have an approximate impact of 34,337,594 tertiary students (UNESCO, 2020). Furthermore, due to COVID19 no university declared a transition to online education which lead to a closure or postponement strategy until the end of March (J. Crawford et al., 2020). In the Philippine, schools and colleges were delayed and most were even confronted with unique technological learning difficulties (Talidong \& Toquero, 2020).

Added to the international context that the pandemic is generating, Arab countries' responses to the risk of a new coronavirus have the potential to compound 
some of the problems already encountered (Fernández, 2020). In the Middle East, actions are anticipated to depart the flailing economies of those countries with scars, especially in Arab nations. Fernández (2020), points out the epidemic COVID19 transmitted in a period when different kinds of threat are being exerted on the Arab region. For example, in Jorden, the epidemic issues of COVID19 would have a long influence, so that Jordan's universities must make audacious efforts in the introduction and implementation of efficient management (Alharbi, 2020). Egypt has closed indefinitely universities and other academic institutions, just like other Arab countries (Reuters, 2020a). A lot of students suffer from this closing however, some of private colleges took measures to complete their teaching online (J. Crawford et al., 2020). As a result of this worldchanging situation, UAE higher education institutions have been unexpectedly forced into a modern digital environment and all UAE universities have instantly transferred their teachings online (KHDA, 2020).

\subsection{Pre-Covid 19 in Yemen}

The conflict in Yemen began in 2011 then escalated dramatically in the last five years. The crisis is identified as the worst humanitarian crisis of the world by the United Nations (UN News, 2020a). Yemen was already struggling against a deteriorated and delicate healthcare system before COVID19 with more than half of its hospitals lost after a fiveyear long and catastrophic military conflict (Lootsma, 2020). Moreover, in terms of economics, much of the Yemeni government sector experienced a wage problem, in particular for teachers, because of the volatility of the Yemeni Rial and the Central Bank of Yemen. According to Supreme Council of Education Planning (2015), there are 16 public universities (6 of them still under construction), 38 private universities, total of student enrollment for (Public \&Private) is 311,000 and 8764 teaching staff and assistants for Public universities (Al-Haimi, Hamid, \& Hujainah, 2018). In general, the ongoing conflict has affected education seriously. The education system suffers from major differences, e.g. the ineffective academic system, the unstable relationship between educators and learners, shortage of effective instructional systems, disinterest in rural education, indifference, disregard for education, etc. HEIs were already struggling to address existing issues, but now with the addition of COVID19, it is an extra stress for them to properly respond to the outbreak.

\subsection{Covid 19 Entry in Yemen}

Yemen registered its first COVID19 case in early April when the healthcare system buckled under COVID19 an added burden (UN News, 2020b). As of June5, 2020, Yemen Supreme National Emergency Committee report that there have been 453 cases and 103 deaths (worldometers, 2020). COVID19 is a crisis that leaves behind the current problems, such as war, starvation and other widespread viral diseases such as cholera, malaria and dengue fever (Lootsma, 2020). Corona is another major problem for the already depreciating country. As a response, The United Nations agencies and their global partners are searching for $\$ 2.41$ billion in the fight against the propagation of 
COVID19 in Yemen while still supporting thousands of people impacted by one of the worst humanitarian crises worldwide (UN News, 2020b).

This is a critical time for education sector in Yemen and it is estimated to affect 267,498 tertiary learners in Yemen (UNESCO, 2020). Yemen has a financial dysfunctional problem already. Therefore, the lockdown caused ambiguity in the examination periods. The outcome is a decline in internships, assignments and lower fees compilation, triggering obstacles to financial performance. The condition is quite complicated in developing countries and, if we do not act adequately, the massive unequal opportunities - unthinkable and unreasonable to begin with - are intensified (Saavedra, 2020). HEIs in Yemen will face significant challenges and what we need to avoid or minimize as much as possible is for those challenges that could cause an even larger negative effect on higher education institutions. The table below summarize the extreme crisis in Yemen:

Table 2.1: Comparison of Extreme Crisis in Yemen

\begin{tabular}{|c|c|c|c|}
\hline & War Conflict & Cholera & COVID19 \\
\hline Reason & Conflict of Interest & $\begin{array}{l}\text { Collapsing health, } \\
\text { water and sanitation } \\
\text { systems }\end{array}$ & $\begin{array}{l}\text { Under investigation, } \\
\text { related to the virus that } \\
\text { caused the SARS } \\
\text { outbreak in } 2003\end{array}$ \\
\hline Nature of impact & Episodic & Episodic & Exponential Growth \\
\hline Scope of impact & National & Regional & Global \\
\hline Human casualties & $\begin{array}{l}100,000 \text { since } 2015 \\
\text { (Reuters, 2020b) }\end{array}$ & 3,886 (WHO, 2019) & $\begin{array}{l}103 \text { in Yemen, as of } \\
\text { June 5, } 2020 \\
394,552 \text { worldwide as } \\
\text { of June 5, } 2020 \\
\text { (worldometers, 2020) }\end{array}$ \\
\hline Time horizon & 5 Years (ongoing) & $\begin{array}{l}\text { Two waves started in } \\
\text { October 2016, April } \\
2017 \text { and still ongoing }\end{array}$ & $\begin{array}{l}\text { Difficult to anticipate, } \\
\text { possibly from } 1-2 \text { years } \\
\text { worldwide }\end{array}$ \\
\hline Infrastructure impact & $\begin{array}{l}\text { Partial lockdown } \\
\text { Suspension of flights in } \\
\text { conflict zone }\end{array}$ & $\begin{array}{l}\text { Partial effect on some } \\
\text { educational and health } \\
\text { institutions }\end{array}$ & $\begin{array}{l}\text { All governorates shut } \\
\text { down in Yemen / } \\
\text { lockdown in other } \\
\text { countries }\end{array}$ \\
\hline Impact on HEIs & $\begin{array}{l}\text { Medium-term } \\
\text { disruption }\end{array}$ & None & Worldwide disruption \\
\hline $\begin{array}{l}\text { Governmental } \\
\text { response }\end{array}$ & Regional initiatives & $\begin{array}{l}\text { International } \\
\text { humanitarian health } \\
\text { organizations } \\
\text { assistance }\end{array}$ & $\begin{array}{l}\text { UN agencies and their } \\
\text { global partners seek } \\
\text { virtual pledging } \\
\text { conference }\end{array}$ \\
\hline Long-term impact & $\begin{array}{l}\text { Security infrastructure } \\
\text { transformation }\end{array}$ & $\begin{array}{l}\text { Rehabilitate sanitation } \\
\text { networks in cholera } \\
\text { high-risk districts } \\
\text { Public health } \\
\text { infrastructure } \\
\text { transformation }\end{array}$ & $\begin{array}{l}\text { Hybrid Learning } \\
\text { transformation /Online } \\
\text { learning system } \\
\text { Public health } \\
\text { infrastructure } \\
\text { transformation }\end{array}$ \\
\hline
\end{tabular}

Source: Authors' Summary. 


\section{Challenges Facing the Higher Education Institutions in Yemen}

In Yemen, higher education has many complicated academic and administrative issues that significantly destabilize the educational quality and standards (Muthanna, 2015). In many facets, higher education will be challenged by many economic circumstances and educational disparities in low income nations, such as Yemen (Muthanna \& Sang, 2018). Coronavirus (COVID19) Pandemic from the other side, added more troubles to higher education institutions as summarized below:

\subsection{Internet and Infrastructure Weaknesses}

One of the most important challenges of Higher Education Institutions (HEIs) in coping with (COVID19) Pandemic is changing the strategy to deal with the new situation while Yemen is suffering from the speed of internet connection with (0.38 MBPS) which put the country at $207^{\text {th }}$ in the world ranking as the slowest internet connection in the world for the third year in a row (Hananto, 2019). Furthermore, as per a World Bank report (Faek \& El-Galil, 2020), the bottom $40 \%$ of Yemen 's population must devote over $51 \%$ of its earnings only on mobile internet services, which makes it impossible for higher education students to rely solely - during the current situation - on any online classes.

Other challenge regarding the internet infrastructures in Yemen is the lake of internet, fixed telephone lines, limited mobile coverage and devices that facilitate access to the internet outside the main provinces such as desktops, laptops, tablets, smartphones as a result of its high cost for this age group. In addition, there is relatively low number of internet users 7.88 Million which represents $27 \%$ of the total population while the number of mobile phone users exceeds 17.82 Million which represents $60 \%$ of the total population (Kemp, 2020).

\subsection{Cope with Change Difficulties}

Moody's, the credit rating organization, has downsized America's high standard of higher learning from "stable" to "negative," since 30\% of colleges and universities in the US were previously weak and adjusting to financial and instructional improvements needed for the coronavirus outbreak has been challenging for such universities to adjust (Moody's, 2019).

In the same direction, Higher Education Institutions (HEIs) in Yemen had great difficulties preparing for any possible change that might occur to the educational system because of (COVID19) pandemic or any other urgent situations due to the absence of strategic planning and contingency plans.

On the other hand, the educators have concerns because they have not been trained for internet based urgent teaching. Furthermore, In addition, the suspension of classes even in higher education coupled with social isolation and home quarantine can cause anxieties (Talidong \& Toquero, 2020), which may increase their willingness to resist any possible change in the educational system (Talidong \& Toquero, 2020). 


\subsection{Academics Career Stability}

Academics and administrators employees of Higher Education Institutions (HEIs) in Yemen were suffering from low salaries as a result of the crises experienced by the country years ago (UNICEF, 2018). Just a few days after the pandemic (COVID19) has triggered major salary decline, lack of finance, and forced leave (Kartseva \& Kuznetsova, 2020). For instance, there are doubts that the downturn in higher education and income in India will have an impact, where unemployment is projected to hit $30 \%$ by the end of April 2020 (Tripathi, 2020). As a result, it is expected that universities may lay off some of their employees or use other solutions, such as leave without pay, especially if the crisis drags on. On the same perspective, part time academics who live with more sophisticated financial problems after announcing the suspension of studies in Yemeni universities since March 2020 with no available alternatives.

\subsection{University's Financial Stability}

ICEF Monitor report released on 15 April 2020 illustrates the economic effect of the epidemic on higher education and could have serious - short and long term repercussions, such as decreasing student enrollment and a reduction in tuition fees if the outbreak persists for one quarter (Tripathi, 2020).

Inside Higher Ed confirmed in a recent survey that 172 of campus leaders was most concerned about COVID19 and its effect on the long-term concerns are related to financial issues, such as financial stability with $89 \%$ (46 percent very concerned). This survey is a clear indication of the expected lack of financial resources and the immediate need to take an action to ensure financial stability (Lederman, 2020).

From the same perspective, Higher Education Institutions (HEIs) in Yemen are facing shortage in financial stability and it is likely to clash with financial liquidity crisis and cash flow in the short term after around three months of (HEIs) complete paralysis, as Deloitte Financial Services confirmed that the most immediate challenge for most institutions involves cash flow (Deloitte Editors, 2020).

\subsection{The Complexity of Some Applied Disciplines}

Most of the Higher Education Institutions (HEIs) in Yemen can cope and overcome some difficulties related to transformation into more flexible educational system if some of the basic requirements for infrastructure are met, and at the same time, the country's technological infrastructure improves. However, some of these universities which have medical colleges are likely to take other approach for a calculated and gradual transformation.

As Faek \& El-Galil (2020) interviewed a Professor of Immunology and Microbiology at Suez Canal University, as the professor confirmed "We 're not equipped for this abrupt transition". As a result, some scholars express alarm regarding online medical education. "The progression of the existing efforts to move to online learning in view of the underdeveloped infrastructure and the lack of training needed for the parties in the learning process does not really gain scientifically and academically." 
Most medical schools worldwide have begun swiftly to transmit their curricula from face to face to online delivery using some digital platforms in reaction to the COVID19 epidemic. Nevertheless, there are also fears about major difficulties and medical educators in these countries have not been sufficiently understood because of the anticipated results and the quality of scientific research cannot be accomplished (Cecilio-Fernandes, Parisi, Santos, \& Sandars, 2020), as a result, clinical and medical studies, lab tests, practicals, and performance tests are not possible to conduct online (Sahu, 2020).

\subsection{Student's Mental Health}

In Yemen, as the global situation, because of the spread of the epidemic, students are living with fear that their families are susceptible and at risk of infection (Zhai \& Du, 2020). As a result, in compliance with the instructions issued by the competent medical authorities, most university students are obligated to stay in their homes for a long time thinking of things related to: self and family health, infection and protection, semester postpone or/and cancellation, exams, financial difficulties, etc. which increase the possibility of causing mental health problems such as stress, anxiety, depressive symptoms, insomnia, denial, anger, and fear (Kang et al., 2020).

\subsection{Costs of Fast Transformation}

Some improvement in the university's infrastructure is expected in the coming period to face such events in the future, but these improvements have technical and institutional costs and factors will stand in front of any rapid transition in the educational system of Higher Education Institutions (HEIs) in Yemen, such as lack of understanding of online pedagogy and online learning styles, lack of administrative support for online education, faculty qualifications.

In the same way, online transition could reduce educational efficiency, enhance skilled education expenses, increased faculty training costs, prejudice of employers against online degrees, insufficient coverage for all subjects / course contents, technological update maintenance expenses, program launch costs and difficulties, reduced communication among educators and students, and possible transgression on the current programs (Palvia et al., 2018).

\section{Recommendations}

After discussing the most prominent challenges facing higher education institutions in Yemen, a set of recommendations are provided to help the educational sector to overcome the impact caused by (COVID19) pandemic or any other emergency conditions that prevent traditional education in the future. 


\subsection{Establishing Hybrid Education System}

Because of the complex and interrelated problems such as lack of infrastructure, the high cost of transformation to online systems, the difficulty of evading traditional education in some applied disciplines in medical and engineering colleges, which prevent Higher Education Institutions (HEIs) in Yemen from a rapid transition to e-learning system. Therefore, a proposal for gradual transformation of Hybrid Education System according to a strategic plan for the next five years, under the direct supervision of the Ministry of Higher Education in Yemen. The gradual transformation begins in several stages, starting with the integration of the hybrid system in education in matters that do not directly affect the transfer of information to the student such as homeworks, reports, assignments and some midterm exams.

\subsection{Cooperation Between Public and Privet Universities}

The rapid spread of the pandemic requires faster response from Higher Education Institutions (HEIs) in Yemen, as a result, the key to overcome this crisis is to think innovatively and work collaboratively instead of competitively and turn the damage into opportunity for 'Academic Impact' shared by the private and public universities. Considering the suffocating crisis that is currently affecting universities due to paralysis in the educational process resulting consequences such as financial liquidity and lack of cash flow it is time to think differently and establish a shared hybrid system to ensure quality standards and wider vision of what flexibility of learning can provide.

\subsection{Training the Next Generation of School Students}

The key to a successful planning and implementing hybrid education system begins with flexibility of change, which should begin at earlier stages in students' lives to be able to develop their mindsets easier. Authors are suggesting a cooperation between the Ministry of Education, schools and the other educational institutions. Ministry of Education may start the implementation of the hybrid education system in a selected schools with stressing the necessity for the Ministry of education to supervise the implementation of the system and the training of the students which could be circulated to other schools later on according to a deliberate strategic plan.

\subsection{Employees Training of Higher Education Institutions}

Higher education institutions should establish a department affiliated to the Quality Assurance Management in educational institutions whose purpose is to ensure the training of academics and workers in these institutions on the application of onlineblended learning approach/hybrid learning system and improve Information and Communication Technology (ICT) resources and capacities, then submit their periodic reports to the university's presidency to be sent later on to the Ministry of Higher Education whose role is to follow up and evaluate these reports to ensure that training is implemented according the ministry's strategic plan. 


\subsection{Activate an Electronic Portal for Each University}

Years ago, The Ministry of Higher Education in Yemen, established the Information Technology Center which provide services relying on information and communication technologies to improve the educational process and scientific research, which are provided based on a study of the needs of the Yemeni society and the higher education sector. Through this center it is recommended to establish a separate electronic portal for each private and public university through which it can be able to provide the necessary infrastructure electronic services to the students. This will positively reflect on all parties interested in developing the higher education sector, starting with the student by raising awareness of the importance of electronic transactions through universities, whereas it will provide a database for Higher Education Institutions which will reduce the direct transactions with students and increase the organizational performance of these institutions.

\section{Conclusion}

The most threatening COVID19 pandemic hit the whole world and have strong implications that will re-shape the future of the region. HEIs worldwide is affected by the emergence of COVID19, universities from around the world have been uncertain which lead to the closure of thousands of schools in order to implement socially distant measures. The global epidemic opened several chances for countries to re-shape its educational system and focus on emerging technologies. Wealthy countries are more willing to move to online learning, but middle \& poorer countries will face hard time to cope with the change. With the ongoing conflict, the worst humanitarian crisis and COVID19, HEIs particularly in the Yemen will face obstacles in the short-term period. This paper discussed how other countries respond during COVID19, current challenges facing HEIs in Yemen and several recommendations for the future. Authors are not calling for an immediate transformation to online educational system because of the challenges mentioned above and other Socio-Economic challenges facing Yemen. However, we believe with the implementation of these suggestive recommendations to the HEIs will move forward and ensure the overall progress in establishing Hybrid Education System under supervision of the Ministry of Higher Education in Yemen.

\section{About the Author(s)}

Ahmed Abdulkarem Al-Baadani is the Secretary-General of the Emirates International University, Yemen. With more than ten years of experience focusing on academic and office organization, marketing management, social media marketing, customer relationship management and interested in the fields of Higher Education and International Marketing.

Mohammed Abbas has completed his PhD in Marketing from Anadolu University, Turkey in May 2019. He received Master of Business Administration - Marketing in 2008 and degree of Business Information Technology in 2006 from Malaysia. Previously, he 
had an experience in banking sector and worked as a lecturer in private university. His research interests focus on international marketing, field of education, social media and environmental studies.

\section{References}

Al-Haimi, B., Hamid, A., \& Hujainah, F. (2018). Factors affecting Yemen higher education institutions performance: Challeneges \& obstacles. International Journal of Engineering and Technology, 256-260. https://doi.org/10.14419/ijet.v7i3.21.17169

Alharbi, M. (2020). The Economic Effect of Coronavirus (COVID-19) on Higher Education in Jordan: An Analytical Survey. International Journal of Economics and Business Administration, VIII(2), 521-532. https://doi.org/10.35808/ijeba/479

Bassett, R. M., \& Arnhold, N. (2020). COVID-19's immense impact on equity in tertiary education. $\quad$ Retrieved June 1, 2020, from https://blogs.worldbank.org/education/covid-19s-immense-impact-equitytertiary-education

Bedford, J., Enria, D., Giesecke, J., Heymann, D. L., Ihekweazu, C., Kobinger, G., ... Wieler, L. H. (2020). COVID-19: towards controlling of a pandemic. The Lancet, 395, 1015-1018. https://doi.org/10.1016/S0140-6736(20)30673-5

Cecilio-Fernandes, D., Parisi, M. C. R., Santos, T. M., \& Sandars, J. (2020). The COVID-19 pandemic and the challenge of using technology for medical education in low and middle income countries. MedEdPublish, 9(1), 1-7. https://doi.org/10.15694/mep.2020.000074.1

Chahrour, M., Assi, S., Bejjani, M., Nasrallah, A. A., Salhab, H., Fares, M., \& Khachfe, H. H. (2020). A Bibliometric Analysis of COVID-19 Research Activity: A Call for Increased Output. Cureus, 12(3). https://doi.org/doi:10.7759/cureus.7357

Crawford, Joseph, Kerryn Butler-Henderson, Jürgen Rudolph, Bashar Malkawi, Matt Glowatz, Rob Burton, ... Sophia Lam. (2020). COVID-19: 20 countries' higher education intra-period digital pedagogy responses. Journal of Applied Teaching and Learning, 3(1), 4-13. http://dx.doi.org/10.1680/geot.2008.T.003

Deloitte Editors. (2020). COVID-19 impact on higher education Confronting financial challenges facing colleges and universities. Retrieved from https://www2.deloitte.com/us/en/pages/public-sector/articles/covid-19-impacton-higher-education.html\#1

Dennis, M. (2020). Higher education opportunities after COVID-19. Retrieved June 1, 2020, from

https://www.universityworldnews.com/post.php?story=20200507152524762

Duffin, E. (2020). Impact of the coronavirus pandemic on the global economy - Statistics \& Facts. Retrieved May 27, 2020, from https://www.statista.com/topics/6139/covid-19-impact-on-the-global-economy/ 
Faek, R., \& El-Galil, T. A. (2020). The Shift to Online Education in the Arab World Is Intensifying Inequality. Retrieved May 31, 2020, from https://www.alfanarmedia.org/2020/04/the-shift-to-online-education-in-the-arab-world-isintensifying-inequality/

Fernández, H. A. (2020). Coronavirus in Arab countries: passing storm, opportunity for change or regional catastrophe? Elcano Real Institute.

Hananto, A. (2019). Rank of Countries with Fastest (and Slowest) Internet in The World 2019. Retrieved May 30, 2020, from https://seasia.co/2019/07/12/rank-of-countrieswith-fastest-and-slowest-internet-in-the-world-2019

Kang, L., Li, Y., Hu, S., Chen, M., Yang, C., Yang, B. X., ... Liu, Z. (2020). The mental health of medical workers in Wuhan, China dealing with the 2019 novel coronavirus. The Lancet Psychiatry, 7(3), e14. https://doi.org/10.1016/S2215-0366(20)30047-X

Kartseva, M. A., \& Kuznetsova, P. O. (2020). The economic consequences of the coronavirus pandemic: which groups will suffer more in terms of loss of employment and income? Population and Economics, 4(2), 26-33. https://doi.org/10.3897/popecon.4.e53194

Kemp, S. (2020). Digital 2020: Yemen. Retrieved June 1, 2020, from https://datareportal.com/reports/digital-2020-yemen

Lederman, D. (2020). Presidents Fear Financial, and Human, Toll of Coronavirus. Retrieved June 2, 2020, from https://www.insidehighered.com/news/survey/college-presidents-fear-financialand-human-toll-coronavirus-their-campuses

Lim, I. (2020). Covid-19: What are Malaysia's public universities doing? Online classes and more. Retrieved May 31, 2020, from https://www.malaymail.com/news/malaysia/2020/03/16/covid-19-what-aremalaysias-public-universities-doing-online-classes-and-mo/1847071

Lootsma, A. (2020). Fighting COVID-19 one job at a time. Retrieved June 1, 2020, from https:/www.ye.undp.org/content/yemen/en/home/blog/2020/coronavirus-couldmean-millions-go-hungry.html

Moody's. (2019). Moody's - Outlook for US higher education sector changed to stable from negative on steady revenue gains. Retrieved June 1, 2020, from https://www.moodys.com/research/Moodys-Outlook-for-US-higher-educationsector-changed-to-stable--PBM_1207036

Muthanna, A. (2015). Quality Education Improvement: Yemen and the Problem of the 'Brain Drain.' Policy Futures in Education, 13(1), 141-148. https://doi.org/10.1177/1478210314566734

Muthanna, A., \& Sang, G. (2018). Conflict at Higher Education Institutions: Factors and Solutions for Yemen. Compare: A Journal of Comparative and International Education, 48(2), 206-223. https://doi.org/10.1080/03057925.2017.1298434

Palvia, S., Aeron, P., Gupta, P., Mahapatra, D., Parida, R., Rosner, R., \& Sindhi, S. (2018). Online Education: Worldwide Status, Challenges, Trends, and Implications. 
Journal of Global Information Technology Management, 21(4), 233-241. https://doi.org/10.1080/1097198X.2018.1542262

Partington, R. (2020). Education hit hardest as coronavirus batters UK economy. Retrieved May 26, 2020, from https://www.theguardian.com/uknews/2020/apr/15/watchdog-identifies-sectors-hit-hardest-by-covid-19-in-britain

Reuters. (2020a). Egypt shuts schools, universities for two weeks as virus cases increase. Retrieved May 31, 2020, from https://www.reuters.com/article/us-healthcoronavirus-egypt/egypt-shuts-schools-universities-for-two-weeks-as-viruscases-increase-idUSKBN2110SH

Reuters. (2020b). Exclusive: As COVID-19 cases in Yemen surge, some sources see undercounting. Retrieved June 1, 2020, from https://www.reuters.com/article/ushealth-coronavirus-yemen-outbreak-exc/exclusive-as-covid-19-cases-in-yemensurge-some-sources-see-undercounting-idUSKBN22P0OO

Ross, J., \& Lau, J. (2020). Universities brace for lasting impact of coronavirus outbreak. Retrieved May 31, 2020, from https://www.timeshighereducation.com/news/universities-brace-lasting-impactcoronavirus-outbreak\#

Saavedra, J. (2020). Educational challenges and opportunities of the Coronavirus (COVID-19) pandemic. Retrieved June 1, 2020, from https://blogs.worldbank.org/education/educational-challenges-andopportunities-covid-19-pandemic https://doi.org/10.1080/1097198X.2018.1542262

Sahu, P. (2020). Closure of Universities Due to Coronavirus Disease 2019 (COVID-19): Impact on Education and Mental Health of Students and Academic Staff. Cureus, 2019(4), 4-9. https://doi.org/10.7759/cureus.7541

Talidong, K. J. B., \& Toquero, C. M. D. (2020). Philippine Teachers' Practices to Deal with Anxiety amid COVID-19. Journal of Loss and Trauma, 1-7. https://doi.org/10.1080/15325024.2020.1759225

The Knowledge and Human Development Authority. (2020). Retrieved May 31, 2020, from https://www.khda.gov.ae/en/safetyatuniversities

Toquero, C. M. (2020). Challenges and Opportunities for Higher Education amid the COVID- 19 Pandemic: The Philippine Context. Pedagogical Research, 5(4), em0063. https://doi.org/10.29333/pr/7947

Tripathi, S. K. (2020). COVID-19 and Higher Education: Learning to Unlearn to Create Education for the Future. Retrieved June 1, 2020, from https://academicimpact.un.org/content/covid-19-and-higher-education-learningunlearn-create-education-future

UN News. (2020a). Humanitarian crisis in Yemen remains the worst in the world, warns UN. Retrieved May 31, 2020, from https://news.un.org/en/story/2019/02/1032811

UN News. (2020b). Yemen: Humanitarians seeking $\$ 2.41$ billion to keep aid flowing amid COVID-19 pandemic. Retrieved June 1, 2020, from https://news.un.org/en/story/2020/05/1064992 
UNESCO. (2020). COVID-19 Educational Disruption and Response. Retrieved May 31, 2020, from https://en.unesco.org/covid19/educationresponse/

UNICEF. (2018). Yemen Humanitarian Situation Report. Sana'a.

UNIDO. (2020). Coronavirus: The Economic Impact. Retrieved May 30, 2020, from https://www.unido.org/stories/coronavirus-economic-impact

WHO. (2019). Cholera Situation in Yemen. Retrieved June 1, 2020, from https://applications.emro.who.int/docs/YEM/YEM-Chol-Nov-2019eng.pdf?ua=1\&ua=1

World Health Organization. (2020). WHO Director-General's opening remarks at the media briefing on COVID-19. Retrieved May 29, 2020, from https:/www.who.int/dg/speeches/detail/who-director-general-s-openingremarks-at-the-media-briefing-on-covid-19---11-march-2020

Worldometers. (2020). COVID-19 Coronavirus Pandemic. Retrieved June 5, 2020, from https://www.worldometers.info/coronavirus/

Zhai, Y., \& Du, X. (2020). Mental health care for international Chinese students affected by the COVID-19 outbreak. The Lancet Psychiatry, 7(4), e22. https://doi.org/10.1016/S2215-0366(20)30089-4

Zhaohui, W. (2020). How a top Chinese university is responding to coronavirus. Retrieved May 29, 2020, from https:/www.weforum.org/agenda/2020/03/coronavirus-china-the-challenges-ofonline-learning-for-universities/

Zhong, R. (2020). The Coronavirus Exposes Education's Digital Divide. Retrieved May 28, 2020, from https://www.nytimes.com/2020/03/17/technology/china-schoolscoronavirus.html 

will be applied to their work. Under the terms of this license, no permission is required from the author(s) or publisher for members of the community to copy, distribute, transmit or adapt the article content, providing a proper, prominent and unambiguous attribution to the authors in a manner that makes clear that the materials are being reused under permission of a Creative Commons License. Views, opinions and conclusions expressed in this research article are views, opinions and conclusions of the author(s). Open Access Publishing Group and European Journal of Education Studies shall not be responsible or answerable for any loss, damage or liability caused in relation to/arising out of conflicts of interest, copyright violations and inappropriate or inaccurate use of any kind content related or integrated into the research work. All the published works are meeting the Open Access Publishing requirements and can be freely accessed, shared, modified, distributed and used in educational, commercial and non-commercial purposes under a Creative Commons Attribution 4.0 International License (CC BY 4.0). 